JURNAL DAKWAH DAN KOMUNIKASI

\title{
KOMUNIKA
}

\section{TERAPI PENYAKIT HATI MENURUT IBN TAIMIYAH DALAM PERSPEKTIF BIMBINGAN KONSELING ISLAM}

\author{
Kholil Lur Rochman" \\ "Penulis adalah dosen Institut Agama Islam NU (Inisnu) Jepara dan STAIMathol/ul Falah (STAMAFA) Kajen Pati.
}

Abstract: According to Ibnu Taimiyah, spiritual disorder (penyakit hati) is a condition which can destroy human imagination and desire. Spiritual disorder cannot be physically seen and do not cause physical pains. It includes the decrease of one's belief in Allah, His messengers and the Judgement day, riya (feeling proud of demonstrating self's good deeds), being arrogant, stingy, jealous, hedonistic, having too much imagination, forgetting death and the Jugdement day, and some others. This condition can be recognized by the occurrence of laziness to do good deeds, hedonistic mind set, and the like. If someone shows those signs it is really necessary for them to handle this condition. Islamic counseling help people to handle such condition by giving continuous, directed, and systematic treatment to develop their spiritual potentials optimally. An Islamic counselor can help a client to face and solve their spiritual problems to live in a harmonious life. Keywords: spiritual disorders, Ibnu Taimiyah, Islamic counseling.

\section{PENGANTAR}

Manusia modern dewasa ini tidak bisa dilepaskan dari kehidupan yang hedonis, kapasitas, dan liberal. ${ }^{1}$ Manusia yang hidup pada zaman yang serba canggih ini, dengan iptek sebagai andalannya, terkadang sering memberikan perubahanperubahan yang tidak pasti, baik dalam bidang hukum, politik, budaya, moral, norma, nilai, dan etika kehidupan, yang semua itu berakselerasi dengan cepat. Semakin cepat perubahan itu, maka semakin maju pula masyarakat dan konsekuensinya tuntutan hidup yang harus dipenuhi oleh masing-masing individu juga semakin meningkat. Akibat orientasi hidup masyarakat modern selalu diarahkan pada waktu, materi, dan prestasi. Dari sinilah manusia akan memikirkan diri sendiri atau merasa bahwa ia perlu terlebih dahulu memikirkan kepentingan dirinya (egois). Selanjutnya, akan berakibat pada timbulnya persaingan hidup dan ending-nya orang kehilangan pegangan kehidupan, hanyut terbawa arus globalisasi. Dengan hilangnya pegangan hidup itu, manusia menjadi tidak mempunyai jati diri, peniruan-peniruan sering mereka lakukan (imitasi) untuk bisa dikatakan mempunyai jati diri. Oleh karena itu, orang sering tidak mampu mengatasi masalah-masalah yang dihadapi sehingga menimbulkan ketegangan atau stres yang memicu munculnya berbagai penderitaan. Secara kejiwaan, merekajuga dipenuhi rasa gelisah dan khawatir. ${ }^{2}$

Menurut Najid Burhani, secara alamiah, manusia merindukan kehidupan yang tenang dan sehat, baik jasmani maupun ruhani. Kesehatan yang bukan hanya terkait dengan badan, tetapi juga mental. ${ }^{3}$ Di sisi lain, kalau dulu orang mengatakan bahwa mental yang sehat terletak di dalam badan yang sehat, maka sekarang terbukti sebaliknya yaitu kesehatan mental menentukan kesehatan badan. ${ }^{4}$ Menurut Kartini Kartono, mental yang sehat adalah kemampuan seseorang memecahkan segenap keruwetan batin manusia yang ditimbulkan oleh berbagai kesulitan hidup, serta berusaha mendapatkan kebersihan jiwa, dalam pengertian tidak terganggu oleh ketegangan, ketakutan dan konflik batin. 5 


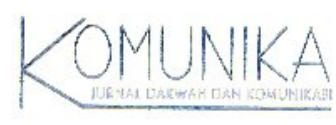

Hati nurani adalah salah satu aspek terdalam dalam jiwa manusia yang senantiasa menilai benar salahnya perasaan, niat, angan-angan, pemikiran, hasrat, sikap dan tindakan seseorang, terutama dirinya sendiri. Sekalipun hati nurani ini cenderung menunjukkan hal yang benar dan hal yang salah, tetapi tidak jarang mengalami keragu-raguan dan sengketa batin sehingga seakan-akan sulit menentukan yang benar dan yang salah. ${ }^{6}$ Tempat untuk memahami dan mengendalikan diri itu ada di hati. Hatilah yang menunjukkan watak dan diri kita sebenarnya. Hati atau "kalbu"-lah yang membuat manusia mampu berprestasi, bila hati bening dan jernih, insya Allah, keseluruhan diri manusia akan menampakkan kebersihan, kebeningan, dan kejernihan. ${ }^{7}$

Hati menjadi esensi dari perilaku dan kehidupan manusia, jika hatinya baik maka perilaku seseorang akan baik, tetapi bila hati buruk, maka akan berakibat negatif bagi perilaku manusia. Hati yang buruk inilah yang sering disebut sebagai hati yang berpenyakit. Penyakit hati mampu merusak gambaran dan kehendak hati. Gambaran tentang syubhat (hal-hal yang samar) membuatnya tidak mampu melihat kebenaran, atau bahkan ia melihat kebalikannya. Akibatnya, orang yang terjangkit penyakit hati akan membenci kebenaran yang bermanfaat dan menyukai kebatinan yang membawa kepada kemudharatan. ${ }^{8}$ Pada bagian lain, Ibnu Taimiyah berpendapat bahwa penyakit hati akan merusak pandangan hidup dan keinginan hati sehingga seseorang menempuh jalan subhat. Baginya, kebatilan merupakan jalan yang benar sehingga keinginannya adalah membenci kebenaran yang bermanfaat dan menyukai kebatinan yang merusak. Penyakit hati dalam perspektif Ibnu Taimiyah lebih berkaitan dengan nafsu syahwat yang termanifestasikan dalam bentuk, iri, dengki, sombong, khasut, serang mencela, tidak syukur nikmat, dan selalu bersifat kurang (serakah).

Apabila manusia berada dalam kondisi hati yang sakit, maka perlu mengobati penyakit ini sehingga dia dapat kembali kepada Islam dengan benar. Hatipun kemudian menjadi selamat dan bersih dari noda-noda sehingga dapat hidup dengan cahaya Allah. ${ }^{9}$ Sudah sewajarnya apabila penyakit itu disembuhkan, dan lebih efektif lagi adalah tindakan preventif (pencegahan) dan represif(pelenyapan penyakit atau pengobatan).

Upaya untuk membersihkan hati ini jika dikaitkan dengan kegiatan dakwah sangat terkait, terutama dakwah dalam artian membimbing dan mengajak ke arah yang lebih baik. Pemahaman ini akan tampak jelas apabila kegiatan berdakwah dipahami dalam bingkai historisitas melalui penjelasan Qur'an dan rangkaian sejarah kehadiran pada Nabi dan Rasul. Dalam hal ini, tampak bahwa mereka hadir pada kondisi sosial manusia yang sedang mengalami degradasi moral dan dehumamisasi ${ }^{i}$ sehingga pantas apabila Murtadha Muthahari mengatakan bahwa pesan mendasar para nabi adalah berjuang menentang kediktatoran, penindasan dan memerangi yang memberontak terhadap perintah Tuhan serta banyak berbuat kerusakan sebagaimana Al-Qur'an juga memberi penekanan mengenai hal ini."

Tujuan utama dakwah menurut Ahmad Mubarok adalah mengubah tingkah laku manusia, dari yang negatif menuju tingkah laku positif. Hal ini dikarenakan tingkah laku manusia bersumber dari jiwa, maka dakwah yang efektif adalah yang bisa diterima oleh jiwa yakni oleh cara berfikir dan cara merasa mad'u. Dakwah seperti inilah yang disebut dakwah persuasif."2 Dengan pemahaman semacam inilah, maka pemikiran Ibnu Taimiyah tentang pengobatan penyakit hati dapat diaplikasikan dalam bentuk dakwah untuk mengubah jiwa manusia dengan cara yang persuasif. Seperti dikonsepkan oleh Donnel;

Kata kunci dari persuasif adalah mempengaruhi, yakni bagaimana dai dapat mempengaruhi mad'u sedemikian rupa sehingga mad'u menerima ajaran dai tetapi seakan merupakan tuntutan mad'u sendiri. Anatomi komunikasi persuasif sendiri sebenarnya cukup kompleks karena ia melibatkan dua pihak yang memiliki kompleksitas simbol. Proses ini dapat diurai dengan membagi menjadi empat komponen yaitu, realitas, dai dan mad'u sebagai individuyang otonom, lingkungan dari dai dan mad’u dan proses penyampaian dan penerimaan pesan dakwah. ${ }^{3}$

Melalui pengertian dakwah semacam ini, dakwah sama sekali bukan hanya kegiatan mimbar untuk mengindoktrinasi sesama tentang kandungan ajaran suci, melainkan mentransformasi (secara individual dan masyarakat) dari realitas yang memalingkan diri dari fitrahnya. ${ }^{4}$ Dalam perspektif inilah bimbingan konseling Islam menjadi varian penting dalam dakwah kontemporer untuk menyelamatkan manusia modern dari keterbelengguan rutinitas kehidupan kapitalis hedonis yang memicu iri hati, dengki, munafik, sombong dan penyakit hati lainnya yang dapat memicu pembinasaan antara sesama manusia dan peradaban. 5 


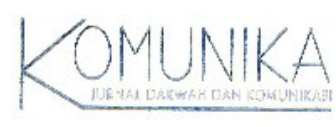

Dari deskripsi di atas, dapat dipahami bahwa penyakit hati merupakan penyakit yang berbahaya, yang tidak mudah untuk dideteksi sehingga upaya Ibnu Taimiyah dalam mengonsep penyakit hati layak untuk dikaji lebih lanjut. Hubungannya dengan dakwah, khususnya bimbingan dan konseling Islam, bisa dilihat dari upaya yang dilakukan oleh Ibnu Taimiyah dengan memberikan bimbingan pada tingkat wacana kepada individu untuk terhindar dari rasa dengki, iri, sombong, dan suka mencela yang kesemuanya akan mendatangkan merugikan bagi dirinya sendiri. Hal ini selaras dengan konsep bimbingan penyuluhan Islam yang menurut Ainur Rahim diartikan sebagai proses pemberian bantuan terhadap individu agar dalam kehidupan bermasyarakat senantiasa selaras dengan ketentuan dan petunjuk Allah sehingga dapat mencapai kebahagiaan di dunia dan akhirat. ${ }^{16}$

Ada rumusan dasar dari bimbingan konseling Islam yaitu, pertama, membantu individu mewujudkan dirinya menjadi manusia seutuhnya agar mencapai kebahagiaan di dunia dan di akhirat. Kedua, membantu individu agar tidak menghadapi masalah. Ketiga, membantu individu untuk mengatasi masalah yang dihadapi dan yang keempat, membimbing individu agar dapat mengembangkan situasi dan kondisi yang baik sehingga tidak menjadi sumber masalah bagi yang lain. ${ }^{17}$ Dalam konteks seperti inilah hal yang dilakukan oleh Ibnu Taimiyah dengan konsep pengobatan penyakit hati menjadi relefan untuk dikaji alternatif materi dakwah kontemporer.

\section{BIOGRAFI DAN KARYA IBNU TAIMIYAH}

Nama Ibnu Taimiyah adalah Taqiyuddin Ibnu Taimiyah. Dia lahir di kota Haran, Mesopotamia Utara (sekarang termasuk wilayah Turki), pada tanggal 10 Rabiul Awal tahun $661 \mathrm{H}$, bertepatan dengan 22 Juni $1263 \mathrm{M}$. Ia adalah putra seorang alim besar mazhab Hanafi yang bernama Abu Abd as-Salam al Hanani. Ayahnya sangat dikenal sebagai ahli hadist yang genius, ahli mantiq dan pengarang berbagai kitab, sedangkan ibunya ada yang mengatakan seorang Arab dan ada yang mengatakan sebagai orang Kurdi, namun yang jelas ibunya sangat berpengaruh dalam pembentukan kepribadian dan pengajaran Ibnu Taimiyah semasa hidupnya. Taimiyah sebenarnya adalah nama keluarga yang mungkin sekali dari etnis Kurdi, yang terkenal karena kegagahan, keberanian, integritas moral dan kecerdasannya.

Kota Haran diserang tentara Mongol pada tahun $1270 \mathrm{H}$, ketika Ibnu Taimiyah baru berusia 7 tahun sehingga keluarga besar Taimiyah termasuk Ibnu Taimiyah bersama kedua orang tua dan tiga orang saudaranya mengungsi ke Damaskus dan selanjutnya menetap di sana. Ibnu Taimiyah berasal dari keluarga intelektual yang sangat Islami serta dihormati dan disegani masyarakat luas pada masanya (Dirjend Depag : 1992, 143). Ayahnya bernama Syihab al Din al Halim ibn Abdus Salam (627682) adalah seorang alim besar yang di samping sebagai khatib dan imam besar serta guru tafsir dan hadits di Masjid raya Damaskus. Ayahnya juga menjabat sebagai direktur Madrasah Dar-al Hadits al Syukrariyah. Kakeknya, Syaikh Naj al Din Abu al Barakat Abdu al Salam ibn Abd Allah (590-625) adalah seorang alim terkenal dalam bidang tafsir, hadits, ushul fiqh, nahwu dan sebagai pengarang, sedangkan pamannya al Khatib Fakhr al Din juga seorang alim dan pengarang yang produktif pada masanya. Sementara adiknya, Syaraf al Din Abd Allah ibn Abd Halim (698-727) dikenal sebagai seorang yang alim dalam berbagaibidang.

Ibnu Taimiyah semenjak kecil dikenal sebagai anakyang genius dengan kemauan keras dalam belajar, tekun dan cermat, tegas dan teguh pendirian, ikhlas dan rajin beramal. Sejak usia tujuh tahun, ia sudah hafal al-Qur'an. Ibnu Taimiyah memperoleh pendidikan di sekolah ayahnya dan lingkungan keluarganya yang secara turun temurun merupakan tokohtokoh yang alim. Ia juga belajar pada beberapa ulama di kota Damaskus. Gurunya, di samping ayahnya dan pamannya sendiri, adalah Sham al Din Abd Rachman ibn Muhammad ibn Ahmad al Maqdisi (594-682 H), seorang fakih ternama dan hakim agung pertama dari mazhab Hambali di Syria, Mahmud ibn Abd al Qarini ibn Badrun al Maqdisi al Mardami (603-699 H). Al Mamja ibn Ustman bin Ustman bin Saat al Tanawir (631-695 H).

Ibnu Taimiyah yang seumur hidupnya konon tidak menikah, namun dapat menyelesaikan studi keagamaannya secara formal sebelum memasuki usia 17 tahun dan pada waktu yang sama telah mengarang kitab. Dalam usia 20 tahun, ia telah menjadi mufti. Bahkan ketika ayahnya wafat pada tahun $682 \mathrm{H}$ dan Ibnu Taimiyah baru berusia 21 tahun, ia mengantikan 


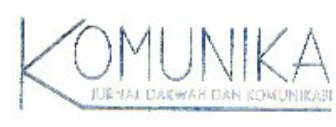

jabatan ayahnya sebagai direktur Dar al Hadits al Sukrariyah. Setahun kemudian, ia memberi kuliah tafsir al-Qur'an di masjid raya Damaskus.

Karya yang di tulis oleh Ibnu Taimiyah di antaranya adalah pertama: Terapi Penyakit Hati, buku ini diterbitkan oleh Gema Insani, Jakarta tahun 1998 yang merupakan terjemahan Jalaluddin Rabba dari buku aslinya berjudul Amradul Qulubi Wasyifauha yang diterbitka oleh Darussalam, Saudi Arabia. Kedua: Mengenai Gerak-Gerik Kalbu, judul asli buku ini adalah Al-Tuhfah Al-Iraqiyah fi al A'mal al-Qalbiyah ya Yaliha Amradh al Qulub wa Syifauha yang diterbitkan oleh Maktabah al Mannar, Yordania tahun 1997, untuk edisi Indonesia diterjemahkan oleh Muhammad al Mighwar dan diterbitkan oleh Pustaka Hidayah, Bandung tahun 2001. Ketiga, Risalah Tasauruf Ibnu Taimiyah, yang diterbitkan oleh al Hikmah, Jakarta tahun 2002. Buku ini merupakan terjemahan dari Majmu Fatawa Syaih al-Islam Ahmad Ibnu Taimiyah

\section{PENYAKIT HATI MENURUT IBNU TAIMIYAH}

Penyakit hati menurut Ibnu Taimiyah adalah suatu bentuk kerusakan yang menimpa hati, yang berakibat dengan tidak mampunya hati untuk melihat kebenaran. Akibatnya, orang yang terjangkit penyakit hati akan membenci kebenaran yang bermanfaat dan menyukai kebatilan yang membawa kepada kemudharatan. Oleh karena itu, kata maradh (sakit) kadangkadang diintepretasikan dengan syakh atau raib (keraguan). Hal ini seperti penafsiran Mujahid dan Qotadah tentang ayat alBaqarah ayat 2 : "Dalam hati mereka ada penyakit". Penyakit dalam ayat ini dipahami sebagai keraguan. ${ }^{18}$ Penyakit hati menurut Ibnu Taimiyah adalah penyakit yang ada di dalam hati, seperti kemarahan, keraguan dan kebodohan dan kezaliman. ${ }^{19}$ Orang yang ragu dan bimbang tentang sesuatu akan merasakan sakit hatinya sampai dia mendapatkan kejelasan dan keyakinan. Akan tetapi, fokus kajian Ibnu Taimiyah tentang penyakit hati adalah hasud atau iri ataupun dengki. Dengki menurutnya, dengan mengambil beberapa pendapat adalah rasa sakit yang disebabkan karena kecemburuan terhadap orangorang yang berharta dan juga sikap berangan-angan atau berharap hilangnya nikmat dari orang lain, meskipun dengan hilangnya nikmat itu ia tidak memperolehnya. Dengkijuga dimaknai sebagai sikap berkeinginan untuk mendapatkan hal yang sama dengan diiringi rasa senang apabila yang dinginkan itu hilang dari orang lain. Secara ringkas, dapat disimpulkan bahwa iri adalah suatu bentuk kebencian dan rasa tidak senang terhadap kenikmatan yang ada pada orang lain. ${ }^{20}$

Secara umum, iri terbagi menjadi dua: pertama, adalah kebencian terhadap nikmat yang ada pada orang lain. Iri semacam ini menurutnya adalah iri yang tercela dikarenakan apabila seseorang terjangkit penyakit ini hatinya akan terasa sakit setiap kali orang lain mendapatkan nikmat dan rasa sakit tu hanya dapat dihilangkan apabila nikmat yang ada pada orang lain itu juga dihilangkan. Padahal, dengan hilangnya nikmat pada orang lain tersebut, dia tidak mendapatkan manfaat apapun. Manfaat yang ia dapatkan hanyalah sebatas hilangnya rasa sakit dalam dirinya. Meskipun demikian, rasa sakit itu akan terus menghantunya manakala nikmat yang diharapkan hilang itu dan ada kemungkinan untuk didapatkan kembali oleh orang yang bersangkutan, baik dalam bentuk yang sama, lebih bagus atau dalam jumlah yang lebih besar. Kedua: perasaan tidak senang kepada orang lain yang mempunyai kelebihan dan akan merasa senang apabila dia juga memperoleh hal yang sama atau lebih bagus. Keadaan semacam inilah yang oleh sebagian orang disebut $g h i b t h a h$.

Menurutnya, iri merupakan penyakit yang diidap oleh sebagian besar manusia dan hanya sebagian kecil saja yang mampu membersihkan hatinya dari penyakit ini. Ada sebuah ungkapan yang menyatakan bahwa "jasad tidak akan terlepas dari iri”, hanya saja seseorang yang berjiwa rendah akan menampakkannya sedangkan mereka yang berjiwa mulia menyembuyikannya. Menurut Ibnu Taimiyah, pada suatu hari, Hasan Basri ditanya, "Adakah seorang Mukmin yang berlaku iri?”, maka Hasan Basri menjawab, "Adakah engkau lupa akan kisah saudara-saudara Nabi Yusuf? Akan tetapi, iri hendaklah engkau sembunyikan dalam hatimu saja. Iri tidak membahayakan dirimu selagi engkau tidak mengungkapnya dengan lisan atau melahirkannya ke dalam bentuk tindakan". ${ }^{21}$ Dengan demikian, siapapun yang di dalam jiwanya ada rasa iri hendaklah dia menggiringnya dengan ketaqwaan dan kesabaran serta membenci iri itu.

\section{PENGOBATAN PENYAKIT HATI MENURUT IBNU TAIMIYAH}




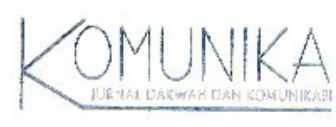

Menurut Ibn Taimiyah, ada tiga hal yang dapat dijadikan sebagai obat penyakit hati yaitu al-Qur'an, amal saleh dan meninggalkan ma'siat. ${ }^{22}$

Pertama: menurut Ibn Taimiyah, al-Qur'an adalah penyembuh bagi penyakit hati yang berada di dalam dada dan bagi orang yang dalam hatinya ada penyakit keraguan dan syahwat. ${ }^{23}$ Di dalamnya terdapat keterangan-keterangan yang menghilangkan kebatilan dan syubhat yang dapat merusak ilmu, pemahaman dan kesadaran hingga segala sesuatu secara hakiki. Di dalamnya juga terdapat hikmah dan nasehat yang baik, seperti dorongan berbuat baik, ancaman dan kisah-kisah yang di dalamnya terdapat pelajaran yang berpengaruh pada sehatnya hati. Hati akan menjadi cinta kepada hal yang bermanfaat dan benci kepada hal yang membawa kepada kesengsaraan. Akhirnya, hati menjadi cinta kepada petunjuk dan benci kepada kesesatan, setelah pada mulanya condong kepada penyimpangan dan antipati terhadap petunjuk.24 Al-Qurân juga merupakan penyembuh dari penyakit yang mendorong kepada kehendak-kehendak buruk. Dengan al-Qur'an, hati dan kehendak menjadi sehat serta kembali kepada fitrahnya sebagaimana kembalinya badan pada keadaan yang semula, yaitu nilai-nilai keimanan dan al-Qur'an yang membawanya kepada kesucian dan menolongnya untuk melakukan perbuatan baik.

Kedua, amal saleh sebagai obat penyakit hati. Menurutnya, hati membutuhkan pemeliharaan supaya dapat berkembang dan bertambah baik menuju kesempurnaan dan kebaikan, sebagaimana tubuh memerlukan makanan yang bergizi. Oleh karena itu, wajib hukumnya untuk mencegah badan dari hal-hal yang dapat membawa pada kemudaratan. Badan tidak akan dapat berkembang dengan baik tanpa memberinya hal yang bermanfaat dan mencegahnya dari hal yang memudaratkannya. Demikian pula hati, ia tidak akan berkembang dengan baik atau mencapai kesempurnaan tanpa memberinya sesuatu yang bermanfaat dan menolak hal-hal yang membawa pada kemudaratan. Demikian pula halnya dengan tanaman, ia tidak akan tumbuh kecuali dengan hal ini. Oleh karena itu, tatkala sedekah dapat menghapus kesalahan sebagaimana air dapat memadamkan api, maka perbuatan baik dapat mensucikan hati dari dosa, sebagaimana firman Allah:Ambillah sedekah dari sebagian harta mereka, dengan sedekah itu kamu bersihkan dan mensucikan mereka(QS.at-Taubah/9:103).

Ketiga, meninggalkan ma'siat sebagai obat penyakit hati. Menurutnya, perbuatan keji dan munkar tak ubahnya seperti campuran kotoran dalam badan dan seperti benalu bagi tanaman. Oleh karena itu, apabila badan telah bersih darinya, maka sehatlah badan tersebut. Demikian pula hati, apabila ia telah bertobat dari dosa-dosa, seolah-olah ia telah menyucikan dari segala yang hal buruk. Oleh sebab itu, apabila hati telah bertobat dari segala dosa, maka akan kembalilah kekuatan hati dan siap untuk menjalankan amalan baik, di samping juga beristirahat dari segala hal yang sifatnya buruk.

Dari deskripsi di atas, menurut Wahib Mu'thi, konsep pengobatan penyakit hati yang tiga tersebut dapat diperinci menjadi beberapa varian, yaitu benar dan ikhlas, taubat, zuhud, wara, sabar, syukur, tawakal, rela kepada Allah, takut, dan mengharap. Macam-macam pengobatan hati tersebut tidak lain merupakan atau sebagian dari sesuatu yang dikemukakan oleh sufi sebagai al-maqomat dan al-akhwal yaitu tahapan-tahapan dan keadaan-keadaan ruhani dalam mendekatkan diri kepada Allah. 25

\section{Benar dan Ikhlas}

Pengobatan hati yang mula-mula dibicarakan oleh Ibnu Taimiyah adalah adalah benar dalam artian kesungguhan dalam beragama yang harus dibuktikan dengan mengerjakan amal kebajikan, sedangkan kata ikhlas adalah bukti dari keislaman. Islam yang dimaksud di sini adalah menyerahkan diri kepada Allah sebagai lawan dari sombong dan menyekutukan Allah. Kata Ibnu Taimiyah, "Barangsiapa yang tidak menyerahkan diri kepada Allah maka ia adalah sombong dan barangsiapa yang menyerahkan diri kepada Allah dan kepada selain Allah maka ia telah menyekutukan".26 Dalam pengertian ini, maka benar dan Ikhlas ditempatkan pada bagian pertama mengenai pengobatan hati. Pemahaman Ibnu Taimiyah mengenai kedua istilah itu memberikan penekanan pada pentingnya amal kebajikan dan berjuang untuk membela agama.

\section{Taubat}




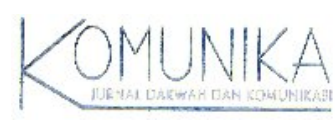

Dalam tasawuf, taubat dipandang sebagai tahapan pertama yang ditempuh oleh sufi dalam proses mendekatkan diri kepada Allah. Secara umum, pengertian taubat meliputi tiga aspek, yaitu meninggalkan perbuatan dosa, mohon ampun kepada Allah, dan tidak akan melakukan dosa selamanya. Dalam tasawuf, pengertian tersebut diperdalam lagi dengan artian taubat tidak hanya meninggalkan perbuatan dosa, tetapi juga meninggalkan segala sesuatu selain Allah. ${ }^{27}$

Menurut Ibnu Taimiyah, taubat merupakan awal dari tahapan penyucian jiwa, tetapi terkait dengan kehidupan manusia yang setiap saat cenderung berbuat dosa, menurutnya suatu dosa akan diampuni Allah dengan sepuluh perkara. Pertama, dengan bertaubat kepada Allah sehingga Allah menerima taubatnya. Kedua, dengan istighfar yaitu memohon ampun kepada Allah sehingga Allah mengampuninya. Ketiga, dengan melakukan amal kebajikan karena amal kebajikan dapat menghapuskan kesalahan. Keempat, karena doa orang yang beriman yang mendoakan kepadanya baik ketika ia masih hidup ataupun sudah mati. Kelima, dengan memberikan kepadanya pahala amal yang bermanfaat. Keenam, karena safaat nabi. Ketujuh, karena cobaan Allah berupa musibah di dunia sehingga cobaan itu menjadi tebusan bagi dosa-dosanya. Kedelapan, karena penderitaan yang dialami di alam barzah. Kesembilan, karena penderitaan di hari kiamat. Kesepuluh, semata-mata karena kasih sayang Allah. Ibnu Taimiyah berkata: "Barangsiapa tidak mendapat salah satu dari yang kesepuluh perkara ini janganlah ia menyalahkan kecuali kepada dirinya sendiri" ${ }^{28}$ Menurut Ibnu Taimiyah, tidak ada dosa yang tidak diampuni oleh Allah apabila orang yang melakukan dosa itu mau bertaubat kepada Tuhan, termasuk dosa menyekutukan Tuhan.

Ajaran Ibnu Taimiyah tentang taubat di atas pada dasarnya mengajak seseorang yang berdosa supaya meninggalkan perbuatan dosanya dan mengisi hidupnya dengan amal kebajikan. Hal ini dia pertegas dengan menyatakan bahwa kesempurnaan taubat adalah dengan melakukan amal kebajikan.

\section{Zuhud dan Wara}

Zuhud menurut Ibnu Taimiyah tidak berarti menjauhkan diri dari kehidupan dunia atau meninggalkan perkara yang dihalalkan yang membawa kepada kebaikan. Sebagai contoh, meninggalkan makanan yang diperlukan tubuh sehingga tidak dapat melakukan kewajiban agama, tidak merupakan zuhud yang dikehendaki oleh agama. Perbuatan demikian adalah salah, karena tidak memperhatikan kepada kebaikan yang harus diutamakan. ${ }^{29}$

Zuhud yang sesuai dengan syariah adalah meninggalkan perkara yang merugikan atau perkara yang tidak bermanfaat untuk kehidupan akhirat, termasuk di dalamnya adalah kekayaan yang berlebihan apabila kekayaan itu tidak dipergunakan untuk beribadah kepada Allah. Singkatnya, zuhud yang benar ialah zuhud dari perkara yang merugikan, bukan zuhud dari perkara yang bermanfaat. Dalam salah salah satu risalahnya, Ibnu Taimiyah menjawab pertanyaan tentang siapakah yang lebih utama, orang kaya yang bersyukur ataukah orang miskin yang sabar. Menurutnya, kekayaan dan kemiskinan bukanlah ukuran keutamaan yang berdiri sendiri. Keutamaan seseorang adalah disebabkan oleh taqwanya kepada Allah. Orang kaya karena taqwanya, maka ia lebih utama dari pada orang fakir, dan sebaliknya. Orang yang sempurna imannya adalah yang dapat menempatkan diri pada masing-masing keadaan dengan bersabar dan bersyukur.

Hal di atas sama dengan persoalan apakah menyepi atau menyendiri dalam beribadah lebih utama daripada bergaul dalam kehidupan masyarakat. Menurut Ibnu Taimiyah, dalam keadaan tertentu pergaulan adalah lebih diutamakan misalnya untuk tolong-menolong dalam melakukan kebaikan, shalat berjamaah, berjuang untuk membela agama dan mengikuti perkumpulan sosial yang bermanfaat, tetapi tetap diperlukan waktu-waktu tertentu dalam kehidupan seseorang di mana ia menyendiri untuk berdoa, berdzikir, tafakkur, muhasabah (introspeksi) dan sebagainya. ${ }^{30}$ Oleh karena itu, memilih pergaulan secara mutlak adalah tidak benar, begitu pula hidup menyendiri secara mutlak adalah tidak benar. Sikap hidup yang benar adalah mengambil apa yang diperlukan dan yang bermanfaat dari keduanya.

Wara' yang sesuai dengan syariah adalah meninggalkan perkara yang haram dan syubhat. Menurut Ibnu Taimiyah, kesempurnaan wara' adalah dengan mengetahui yang terbaik di antara dua perkara yang baik untuk dilakukan dan yang terburuk di antara dua perkara yang buruk untuk ditinggalkan. Melakukan yang paling baik dan meninggalkan yang paling buruk didasarkan atas pertimbangan bahwa ajaran agama pada hakikatnya dibangun atas dasar maslakhah semaksimal 


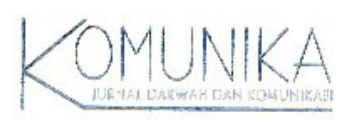

mungkin dan menghilangkan mafsadah hingga sekecil-kecilnya. Dengan demikian, orang yang melakukan perbuatan atau meninggalkannya dengan alasan wara' tidak dapat dibenarkan jika tanpa mempertimbangkan segi maslahah dan mafsadah menurut agama sehingga menyebabkan ia meninggalkan kewajiban dan melanggar larangan.

\section{Sabar dan Syukur}

Berbagai penjelasan Ibnu Taimiyah tentang sabar tidak berbeda dengan penjelasan yang terdapat dalam literatur akhlaq atau tasawuf pada umumnya. Menurutnya, sabar adalah ungkapan hati yang berkaitan dengan penderitaan. Sebaliknya, syukur merupakan keadaan hati yang berkaitan dengan kenikmatan. Syukur dinyatakan dengan memanjatkan pujian kepada Tuhan.

Ibnu Taimiyah menekankan pentingnya memuji dan bersyukur kepada Tuhan dan mejelaskan perbedaan antara keduanya. Dari segi cara menyatakannya, syukur lebih umum sifatnya karena syukur dikerjakan dengan hati, ucapan dan perbuatan, sedangkan memuji Tuhan dinyatakan dengan ucapan saja. Dari segi sebabnya, memuji kepada Tuhan mengandung artiyang lebih umum karena berkaitan dengan segala kebaikan yang dipuji, tidak hanya kebaikan yang ditujukan kepada yang memuji, sedangkan syukur hanya berkenaan kenikmatan yang diberikan kepada orang yang bersyukur.

\section{Tawakal dan Ridha}

Tawakal berarti menyerahkan diri kepada Tuhan untuk tidak bergantung kepada makhluk atau perbuatan yang dilakukan. ${ }^{31}$ Perbuatan hanya merupakan sebab dari terjadinya sesuatu karena tidak dapat berdiri sendiri dalam mewujudkan sesuatu, melainkan harus ada penentu. Penentu bagi keberhasilan usaha tidak lain adalah Tuhan. Oleh sebab itu, manusia harus berserah diri dan memohon pertolongan kepada Tuhan.

Tawakal kepada Allah tidak berarti penyerahan diri secara pasif, tetapi harus disertai dengan usaha dan meminta pertolonga kepada Tuhan. Oleh karena itu, ajaran agama menyuruh manusia agar menyembah kepada Allah dan meminta pertolongan kepadanya. Secara garis besar, Ibnu Taimiyah berpendapat apabila seseorang merasakan hakikat keihlasan dalam beragama yang terkandung dalam ixyakamabudu dan merasakan hakikat tawakat yang terkandung dalam ìyaka nastain, makatidak ada lagi baginya kenikmatan yang di atasnya.

Ibnu Taimiyah menegaskan bahwa tawakal tidak berarti meninggalkan sebab dan menyerah kepada nasib. Dia mengkritik orang-orang yang mengaku menyerahkan diri kepada Tuhan tanpa berusaha dan menjalankan perintahnya. Mereka menyangka bahwa segala sesuatu telah ditaqdirkan Tuhan tanpa digantungkan pada sebab-sebab tertentu yang harus diusahakan oleh manusia.

\section{KONSEP PENGOBATAN HATI MENURUT IBNU TAIMIYAH}

Secara umum, dapat dipahami bahwa pengobatan penyakit hati menurut Ibnu Taimiyah dapat diarahkan pada konsep memahami diri yang difokuskan pada aspek ruhani..$^{32}$ Hal ini didasarkan pada pemikiran bahwa manusia dapat dikatakan hidup jika ruhaninya "hidup". Oleh karena itu, perbincangan mengenai fitrah manusia inipun pasti difokuskan pada pendalaman terhadap hal-hal yang berkaitan dengan ruhaninya. Berkaitan dengan fitrah ruhani ini, Allah berfirman dalam surat al-Syams 7-10yang artinya: "Dan demijüwa serta penyempurnaannya, maka Allah mengilhamkan kepadanya (jalan) kefasikan dan jalan ketakwaannya. Sesungguhnya beruntunglah orang-orang yang mensucikan j̈wa itu dan sesungguhnya merugilah orang yang mengotorinya". Dari ayat ini, dapat diambil kesimpulan bahwa Allah memberi potensi fujur (buruk seperti sombong, dengki, egois dan lain sebagainya) dan juga potensi taqwa (suka menolong, berterima kasih, mau berkorban) kepada ruhani manusia, maka tinggal upaya manusia menangkap tantangan Allah mau mensucikannya.

Menurut Al-Ghazali, ruhani manusia terdiri dari empat dimensi..$^{33}$ Yang pertama adalah ruh. Konsep tentang ruh dapat dipahami dari firman Allah dalam al-Qur'an surat al-Isra : 85 yang menegaskan bahwa masalah ruh adalah urusan Tuhan, manusia hanya sedikit diberi pengetahuan tentangnya. Misalnya ruhlah yang menyebabkan tubuh hidup, tumbuh dan berkembang, bergerak serta berketurunan. Ia ibarat sebuah lampu yang cahayanya tersebar menerangi setiap sudut rumah. 


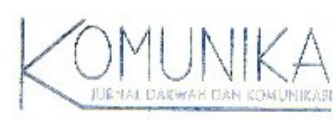

Itulah ruh ini tetap hidup, hanya berpindah tempat yaitu ke alam barzah. Adapun ruh ruhaniyah adalah sesuatu yang halus, yang mengetahui dan merasa yang mengakui Tuhan, namun hanya Allah yang mengerti hakikatnya.

Yang kedua adalah nafs atau jiwa. Menurut ahli tasawuf, nafs atau jiwa adalah kekuatan yang menghimpun sifat-sifat tercela pada manusia (nafs jasmaniyah), yang harus dilawan dan diperangi, yang terdiri dari nafsu amarah (memerintah buruk) dan lawwamah (suka mencela). Itulah nafsu jasmaniah atau lebih dikenal dengan sebutan hawa nafs. Dalam alQur'an surat Yusuf : 53 yang artinya, "Dan aku tidak membebaskan diriku (dari kesalahan) karena sesungguhmya nafsu itu selalu menyuruh kepada kejahatan, kecuali yang dirahmati Tuhanku”. Hawa nafsu menurut al-Ghazali ada empat macam; pertama bahimiyyah (kebinatangan) dengan profil babi. Manusia yang dikuasai olehnya menjadi rakus, tamak, barang kotorkotor pun mau seperti pencoleng, koruptor. Kedua, sabuiyyah (binatang buas) dengan profil serigala, biarpun kecil berani membabat binatang yang jauh lebih besar daripadanya. Manusia yang dikuasainya tega mencelakakan, membunuh, atau mengorbankan orang lain demi kepentingannya. Ketiga, syaithaniyyah (sifat syetan) senang menggoda ataupun menjerumuskan orang lain. Keempat, Uluhiyyah (sifat Ketuhanan), yang dimaksud adalah sifat-sifat yang hanya otoritas Tuhan, yang tidak diperbolekan untuk ditiru, seperti sifat sombong, angkuh, pemaksa, berkuasa, dan sebagainya. Keinginan menyaingi Tuhan inilah hawa nafsu uhuhiyyah dan ini dilarang. Jika meniru sifat Tuhan yang memang diperbolehkan untuk dimiliki justru diperintahkan seperti sifat kasih, sayang, dermawan dan sebagainya. ${ }^{34}$ Agar benar dan mudah dalam menyikapi hawa nafsu yang selalu ada dalam diri manusia, al-Ghazali mengibaratkannya bagai seseorang yang memiliki kuda (baca; kendaraan). Jika dia dapat mengendalikan kuda tersebut, akan nikmatlah hidupnya karena ke manapun ia pergi akan diantar tanpa rasa lelah sampai ketujuan. Akan tetapi, bagi seseorangyang punya kuda tidak dapat mengendarai atau mengendalikan, maka rugilah hidupnya karena dia hanya akan menjadi budaknya kuda, bahkan bisa celaka karenanya. Demikian pula orang yang memiliki hawa nafsu yang tidak dapat mengendalikannya, maka jadilah dia budaknya hawa nafsu dan itu celaka dunia akhirat. Kendali hawa nafsu adalah ajaran agama itu sendiri. Adapun nafsu ruhaniyyah antara lain nafsu muthmainnah yang telah anteng atau tenang dan tenteram dalam naungan Allah, juga nafsu radliyah, mardlizyah yang merelakan dan direlakan Allah kembali keharibaan-Nya, sebagaimana ditegaskan oleh QS. al-Fajr : 27-30. Bagi orang yang jiwanya tenteram dalam iman tentu tidak hanya di akhirat, di dunia akan merasa tenang dan bahagia bagaikan hidup di surga.

Yang ketiga yaitu akal, akal ialah pengetahun tentang segala sesuatu atau keadaan. Akal jasmaniyyah untuk berpikir halhal yang berkaitan dengan materi seperti tentang manusia, hewan, tumbuhan, pekerjaan, ilmu dan sebagainya, namun sebatas yang tampak. Biasanya pembicaraan tentang akal dipahami berkaitan dengan otak, dengan pembagian belahan kiri memiliki kecenderungan dan kepekaan logis, matematis, dan kegiatan spesial sebagai basis rasio, sedang belahan otak kanan memiliki kecenderungan dan kepekaan rasa, aktivitas spontan dan feeling merupakan sumber intuisi. Meski demikian, pembagian itu tidak secara spesial dan rigid karena masing-masing selalu dalam kondisi interaktif. Dalam kajian ilmiah, akal ruhaniyyah menghuni rasa keagaamaan dan kecerdasan spiritual berada di belahan otak kanan, perlu dirangsang dan dihidupkan terus-menerus antara lain dengan ajaran dan nilai-nilai tasawuf. Akal ruhaniyah bisa juga berpikir tentang materi, namun dapat menjelajah dan mengkaitkannya dengan keagungan dan kemahakuasaan Allah sang Pencipta karena instuisi dirinya hidup.

Yang keempat, qalb atau hati. Secara jasmaniyah merupakan segumpal darah atau daging bulat panjang yang berada di dada kiri atas. Itulah jantung sebagai lambang hidup manusia. Secara ruhaniyah adalah hakikat manusia yang halus, yang mengetahui dan mengenal, yang merasa secara mendalam, maka dialah yang diberi peringatan (QS. Qaaf/50:37).

Dari keempat unsur ruhani tadi (ruh, nafs, aql dan qalb) satu sama lain sulit dipisahkan secara dikotomis, biarpun kadang kala fungsi masing-masing bisa dibedakan.

Di sisi lain, pada deskripsi di atas juga dikemukakan bahwa jalan yang ditempuh oleh sufi untuk mendekatkan diri kepada Tuhan ialah dengan penyucian hati. Seorang sufi yang menempuh jalan penyucian hati dapat digambarkan seperti pengembara yang menempuh perjalanan pajang dan penuh dengan berbagai kesulitan. Dalam perjalanan ini, ia harus melintasi tahapan-tahapan (maqomat) dan mengalami keadaan ruhani ( $a$ hwal) sebelum mencapai tujuan akhir, yaitu dekat dengan Tuhan. Menurut teori al-Sarraj, maqomat yang harus ditempuh oleh sufi terdiri dari tujuh macam. ${ }^{35}$ Secara berurutan 


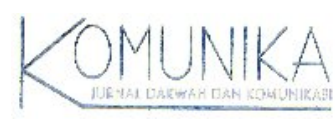

ketujuh maqam tersebut adalah: Taubat (meninggalkan perbuatan dosa), Wara'(meninggalkan perkara subhat dan perkara yang sia-sia), Zuhud (berpaling dari dunia), kefakiran, sabar, tawakal, dan ridha, sedangkan ahwal terdiri dari sepuluh macam yang secara berturut-turut adalah: muraqabah (meditasi untuk mendekatkan diri kepada Allah), Qurb (dekat dengan Tuhan), Mahabbah (cita kepada Tuhan), Khauf (takut kepada Tuhan), Raja (Mengharap kepada Tuhan), Syawq (Rindu kepada Tuhan),Uns (keakraban), Tuma'ninah, Musyahadah (penyaksian terhadap Tuhan), dan Yaqin.

Pemikiran Ibnu Taimiyah tentang pengobatan penyakit hati terkadang ia namakan dengan ahwal dan maqomat. Baik Ibnu Taimiyah maupun para sufi, dalam hal ini membicarakan hal yang sama yaitu sifat-sifat atau keadaan ruhani, seperti taubat, zuhud, wara', cinta kepada Allah dan sebagainya, tetapi apabila kedua pandangan itu diperbandingkan, maka akan tampak beberapa perbedaan yang prinsipil.

Pertama, Ibnu Taimiyah tidak membicarakan pengobatan penyakit hati sebagai tahapan terhadap penyucian jiwa. Ia memandang hal itu sebagai pekerjaan-pekerjaan hati atau keadaan-keadaan hati yang harus dimiliki oleh setiap orang mukmin yang tidak lain adalah ajaran agama yang menekankan segi-segi yang bersifat batin, sedangkan para sufi menjelaskan pengertian ahwal dan maqomat sebagai sistem yang menggambarkan jalan yang harus ditempuh oleh para sufi, yaitu jalan yang terdiri dari tahapan-tahapan ruhani dan keadaan-keadaan hati dalam mendekatkan diri kepada Tuhan.

Kedua, Ibnu Taimiyah menjelaskan pengobatan penyakit hati dari segi pengertiannya yang dinamis dan aktif. Ia menekankan misalnya, taubat hendaklah diikuti dengan mengerjakan kebaikan, kesempurnaan wara ialah dapat menentukan pilihan dan melakukan yang terbaik bari berbagai pilihan yang sama buruknya, tawakal tidak berarti meninggalkan usaha manusia, dan ridha ditandai dengan melakukan perbuatan yang disukai oleh Allah. Berbeda dengan Ibnu Taimiyah, para sufi menekankan makna esoterik dari keadaan-keadaan hati. Mengenai makna esoterik ini, misalnya mereka mengartikan taubat tidak hanya berarti meninggalkan perbuatan dosa tetapi juga meninggalkan segala sesuatu selain Tuhan. Zuhud bagi kaum sufi bukan sekadar meninggalkan kehidupan dunia, tetapi mengosongkan pikiran dari apapun selain Allah.

\section{PENGOBATAN PENYAKIT HATI DALAM PERSPEKTIF BKI}

Rancang bangun pengembangan kajian BKI diarahkan pada pembinaan dan penyuluhan dalam rangka mewujudkan masyarakat baru dengan kualifikasi. Pertama, masyarakat yang beriman dan bertaqwa kepada Tuhan dalam bingkai tatanan masyarakat agamis yang bersifat dinamis dan berorientasi pada moral, demokratis dan beradab yang menghargai adanya perbedaan pendapat, menghargai dan mengakui hak asasi manusia, tertib dan sadar hukum. Kedua, masyarakat yang sadar sebagai bagian dari masyarakat global yang memiliki semangat kompetitif, penuh persaudaraan dengan semangat kemanusiaan universal. Ketiga, masyarakat yang beradab yang menjunjung tinggi nilai-nilai budi luhur yang telah mengakar dalam tatanan masyarakat seperti bersilaturrahim, persaudaraan, persamaan, adil, baik sangka, rendah hati, tepat janji, lapang dada, dapat dipercaya, harga diri dan dermawan. Keempat, masyarakat yang menghargai pendidikan sebagai proses yang berlangsung sepanjang hayat. Penyelenggaraan pendidikan tidak lagi terkait dengan dimensi ruang dan kelembagaan.$^{36}$ Formulasi ini dapat berhasil jika dimulai dengan manajemen hati yang tepat.

Bimbingan konseling Islam, secara konseptual merupakan suatu proses adanya seseorang yang dipersiapkan secara profesional, membantu orang lain, untuk pemahaman diri, pembuatan keputusan dan pemecahan masalah, pertemuan dari hati ke hati dan hasilnya sangat bergantung pada kualitas hubungan. Oleh karena itu, definisi Bimbingan dan Konseling Islam menurut penulis adalah suatu proses hubungan pribadi yang terprogram, antara seorang konselor dengan satu atau lebih klien di mana konselor dengan bekal pengetahuan profesional dalam bidang keterampilan dan pengetahuan psikologis yang dikombinasikan dengan pengetahuan keislamannya membantu klien dalam upaya membantu kesehatan mental sehingga dari hubungan terebut klien dapat menanggulangi problematika hidup dengan baik dan benar secara mandiri yang berpandangan pada al-Qur'an dan as-Sunnah.

Dengan kerangka semacam inilah, maka proses pembersihan jiwa seorang salik dengan cara menyucikan hati dan mengenali virus diri dengan bimbingan seorang guru sufi merupakan salah satu proses Bimbingan konseling Islam yang 
diharapkan mampu memberian bantuan kepada individu agar terhindar dari tekanan-tekanan kejiwaan. Dari proses ini, diharapkan para konselor (guru sufi) mampu memberikan bimbingan secara tepat tentang tasawuf agar tidak disalahpahami dan mampu menawarkan beberapa alternatif pemikiran tentang tasawuf yang peduli pada realitas masyarakat. ${ }^{37}$

Dalam tarap aplikatif, pengobatan penyakit hati Ibnu Taimiyah dalam perspektif BKI dapat diformulasikan dalam beberapa bentukbimbingan sebagai berikut.

\section{Bimbingan dengan Cara Mendidik Hati}

Dari empat unsur ruhani, hati merupakan hal yang terpenting. Hatilah yang dapat menembus ruang dan waktu, merasa, berdialog, berinteraksi dengan siapapun, termasuk dengan Tuhan. Gambaran akan dominannya hati bagi hidup manusia dapat dicermati dari perkataan Nabi Muhammad: "Ketahuilah bahwa di dalam tubuh ini ada segumpal darah, j̈ka ia baik seluruh tubuh akan baik, namun j̈ka ia rusak sehuruh tubuhpun rusak. Ketahuilah ia adalah hati". Namun, kebanyakan orang terpesona dan lebih memperhatikan tampilan fisik, tidak banyak yang menyadari betapa pentingnya merawat hati, mengobatinyajika sakit dan membersihkannya dari kotoran-kotoran yang menempel.

\section{Bimbingan dengan Cara Mengenal Macam-macam Hati}

Menurut Ibnu Taimiyah, ada tiga macam kondisi hati manusia yang bisa ditawarkan dalam proses bimbingan, pertama, hati yang sehat yang bisa menjadi selamat. Ini yang dijanjikan akan bertemu Allah. Ia mempunyai tanda-tanda antara lain, imannya kokoh, mensyukuri nikmat, tidak serakah, hidupnya tenteram, khusyu' dalam beribadah, banyak berdzikir, kebaikannya selalu meningkat, segera sadar jika lalai atau berbuat salah dan suka bertobat. Kedua, hati yang mati, yang telah mengeras dan membatu karena banyak kerak akibat dosa-dosa yang dilakukan sehingga menghalangi datangnya petunjuk Allah. Tanda-tandanya antara lain, tidak ada iman, mengingkari nikmat Alllah, dikuasai hawa nafsu, pikirannya negatif/buruk sangka, tak berperikemanusiaan, egois, keras kepala, dan tak pernah merasa bersalah. Ketiga, hati yang sakit, yang di dalamnya ada iman, ada ibadah ada pahala, tetapi juga ada kemaksiatan dan dosa-dosa baik kecil maupun besar. Tandatandanya antara lain, hatinya gelisah, tidak tenang, suka marah, tidak pernah punya rasa puas, susah menghargai orang lain, serba tidak enak/tidak nyaman, penderitaan lahir batin dan tidak bahagia.

Dari paparan di atas, dapat diambil pelajaran bahwa mutlak bagi kita untuk membersihkan sifat-sifat buruk dengan jalan mengokohkan sifat-sifat baik antara lain: senang bersyukur, berbaik sangka, rendah hati, penuh kasih, sabar, jujur, bersikap adil, lemah lembut, sabar dan jujur. Apabila sifat-sifat baik diwujudkan dalam kebiasaan sikap dan perilaku sehari-hari, niscaya yang muncul adalah tampilan kepribadian yang baik dan simpatik, yang akan menyenangkan siapapun.

Selain itu, resep Allah untuk menghilangkan noktah-noktah hitam yang menempel agar hati bening termaktud dalam QS. Ali Imran/3 : 135 yang mengajarkan: "Dan orang-orang yang apabila telah mengerjakan perbuatan kotor/këi atau menganiaya diri sendiri, hendaklah mengingat Allah dan mohon ampun terhadap dosa-dosa mereka dan siapa lagi yang dapatmengampuni dosa selain daripadaAllah.

\section{KELEBIHAN DAN KEKURANGAN KONSEP PENGOBATAN PENYAKIT HATI MENURUT IBNU TAIMIYAH}

\section{Kelebihan Konsep Pengobatan Penyakit Hati Menurut Ibnu Taimiyah}

Kelebihan pemikiran Ibnu Taymiyah terletak pada kelengkapan data yang terdiri dari Qur'an dan hadits dalam mengkaji persoalan-persoalan keislaman yang terkait dengan persoalan pengobatan penyakit hati secara spesifik dan kajian tasawuf secara umum. Dalam beberapa karya yang merupakan himpunan dari beragam fatwa yang ditujukannya kepada masyarakat, persoalan pengobatan penyakit hati merupakan isu sentral. Terutama isu tentang pembersihan hati dan dan proses untuk membersihkannya. 


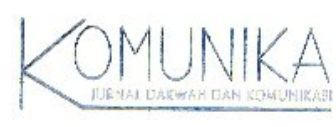

Kelebihan dari pemikiran pengobatan penyakit hati menurut Ibnu Taimiyah adalah upayanya untuk mengaktualisasikan tasawuf dalam lingkup kemasyarakatan. Ini penting dikarenakan sosok Ibnu Taimiyah sangat akrab dengan gagasan purifikasi dan modernisasi sehingga mengkaji sisi lain dari pemikiran Ibnu Taimiyah merupakan hal yang boleh dibilang langka.

\section{Kekurangan Pengobatan Penyakit Hati Menurut Ibnu Taimiyah dalam Perspektif Bimbingan KonselingIslam}

Kekurangan pengobatan penyakit hati menurut Ibnu Taimiyah terletak pada berhentinya wacana tersebut pada dataran teoritis dan belum menyentuh pada wilayah aplikatif seperti misalnya mengenal kondisi masyarakat yang hendak dijadikan objek bimbingan. Dia lebih terfokus pada kajian konseptual yang didasarkan pada normativitas teks sehingga memunculkan konsep-konsep yang variatif, tetapi konsep tersebut berhadapan dengan realitas masyarakat yang berbeda belum tersentuh olehnya. Padahal, setiap lingkungan masyarakat memiliki struktur, nilai-nilai, potensi, kendala dan dinamika masing-masing.

Dalam melaksanakan bimbingan penyuluhan, kondisi tersebut perlu benar-benar dikenali agar jelas hal-hal positif yang perlu ditingkatkan dan hal-hal negatif yang perlu dikurangi dan dihambat supaya tidak berkembang. Ada beberapa aspekyang layak untuk dipertimbangkan sebelum suatu gagasan tersebut didialogkan dengan realitas. Aspek-aspek tersebut meliputi nilai-nilai yang dianut, kebutuhan utama, hal-hal yang peka dan kondisi aktual dari suatu masyarakat ${ }^{38}$

\section{a. Nilai-Nilai yang Dianut Masyarakat}

Dalam kehidupan sosial terdapat berbagai macam nilai, yakni hal-hal yang dianggap penting, benar dan dijunjung tinggi oleh masyarakat serta secara sadar ataupun tidak dijadikan pedoman, tolok-ukur dan orientasi oleh anggota-anggota masyarakat dalam bersikap dan berperilaku. Sebagai contoh adalah nilai-nilai yang dikemukakan oleh Eduard Sprangger, yaitu nilai estetika, nilai teori, nilai politik, nilai sosial, nilai ekonomi, dan nilai religius yang kesemuanya melandasi kehidupan manusia secara universal. Memahami nilai-nilai dominan yang dianut masyarakat sangat penting dalam pelaksanaan bimbingan penyuluhan karena dengan pemahaman itu akan lebih jelas sikap, persepsi, keinginan dan hal-hal yang diterima dan tidak dapat diterima masyarakat, tetapi karena nilai-nilai itu tidak kasat mata, maka para petugas bimbingan perlu mengetahui indikator-indikatornya antara lain, pertama, kecenderungan bertindak dalam menghadapi suatu peristiwa; kedua, hal-hal yang sangat dihargai dan dikecam oleh masyarakat; ketiga, tema-tema pembicaraan tokoh-tokoh panutan masyarakat; dan keempat, apa yang membuat malu, menyinggung perasaan, dan menimbulkan reaksi keras bagi orang banyak. Melalui beberapa indikator ini, diharapkan para pembimbing mampu menyimpulkan nilai-nilai yang dianut oleh suatu masyarakat.

\section{b. Kebutuhan Utama Masyarakat}

Mengetahui kebutuhan utama suatu masyarakat sangat penting bagi para pembimbing karena berkaitan erat dengan masalah motivasi dan upaya memotivasi masyarakat untuk bergerak secara aktif ke arah tujuan pembinaan yang hendak dicapai. Adapun kebutuhan yang mendorong proses perubahan di masyarakat biasanya terjadi karena, pertama, merasakan sendiri adanya kekurangan yang perlu dipenuhi. Kedua, sengaja disadarkan kekurangan dan kebutuhan-kebutuhannya. Ketiga, pengaruh dari pergaulan dan contoh-contoh yang diamati, keempat, rekayasa terencana untuk menawarkan kebutuhan-kebutuhan baru, dan kelima, pergeseran nilai hidup yang menimbulkan berbagai tuntutan. Sehubungan dengan itu, berbagai kebutuhan dasar manusia yang telah diungkapkan oleh para ahli psikologi tampaknya cukup penting untuk diketahui oleh para pembimbing misalnya saja, kebutuhan-kebutuhan dasar bertahap (fisiologi, rasa aman, saling mengasihi, hrga diri, aktualisasi diri) dari Abraham Maslow, teori $E R G$-nya Aldelfer (existence, relatedness, growth) dan lain sebagainya.

\section{c. Hal-hal yang Peka dalam Masyarakat}

Selain perlu mengetahui kebutuhan utama masyarakat, para pembimbing perlu juga memahami apa yang sangat peka bagi masyarakat, yakni hal-hal yang bila dilangggar atau tidak dilakukan akan menimbulkan keresahan dan reaksi keras masyarakat. Hal-hal sensitif ini biasanya berlainan untuk tiap kelompok masyarakat karena apa yang dianggap baik atau buruk oleh masyarakat tersebut.

\section{d. Memahami Kejadian Aktual di Masyarakat}


Para pembimbing sebaiknya selalu mengetahui dari waktu ke waktu kondisi aktual masyarakat dan terus-menerus mengikuti informasi tentang peristiwa-peristiwa yang terjadi di masyarakat. Hal ini penting untuk menyusun topik pembicaran yang aktual, menetapkan tujuan yang benar benar sesuai dengan kebutuhan nyata serta memberi arah yang lebih jelas pada masyarakat binaannya.

\section{IMPLEMENTASI KONSEP PENGOBATAN PENYAKIT HATI MENURUT IBNU TAIMIYAH DALAM REALITAS DAKWAH}

Meminjam terminologi yang dikembangkan oleh Asep Kusnawan yang menyatakan bahwa hakikat dakwah adalah upaya merealitaskan fungsi kerisalahan dan fungsi kerahmatan, maka secara garis besar dapat dirumuskan dari dimensi kerisalahan terdapat dua bidang besar yaitu tabligh dan irsyad. Tabligh adalah penyebarluasan ajaran agama Islam dengan menempuh jalur oral, massal, seremonial, bahkan kolosal, sedangkan irsyad adalah penyebarluasan ajaran Islam yang sangat spesifik di kalangan tertentu.

Irsyad ini menampilkan ajakan personal antara pembimbing dan terbimbing. Ia lebih berorientasi pada pemecahan masalah individual yang dialami oleh terbimbing. Di samping itu, ia juga merupakan penyebarluasan ajaran Islam di kalangan tertentu dengan suatu pesan tertentu. Pesan itu merupakan paket program yang dirancang oleh pelaku dakwah. Ia dirancang secara bertahap sampai pada perolehan target tertentu ${ }^{39}$. Pada posisi inilah konsep pengobatan penyakit hati menurut Ibnu Taimiyah dapat diimplementasikan pada individu-individu dengan pendekatan dakwah model irsyad. Model ini menuntut adanya paket program seperti manajemen hat yang memiliki tujuan utuk membentuk muslim kafah sehingga mampu hidup secara bermakna. Pada wilayah lain, dimensi kerahmatan menggarap dua bidang, yaitu tadbir dan tathwir. Tadbir adalah sosialisasi Islam dengan mengoptimalkan lembaga dakwah, sedangkan tathwir adalah sosialisasi ajaran Islam untuk mempertinggi derajat kesalehan individu dan kelompok sehingga dapat memecahkan masalah yang ada di masyarakat. Pada posisi tathwir juga dapat diimplementasikan konsep Ibnu Taimiyah ini dalam rangka untuk memecahkan masalah yang dihadapi oleh masyarakat dengan mengambil bentuk bimbingan konseling Islam.

\section{IMPLEMENTASI KONSEP PENGOBATAN PENYAKIT HATI MENURUT IBNU TAIMIYAH DALAM BIMBINGAN KONSELING ISLAM}

Secara khusus, implementasi konsep Ibnu Taimiyah tentang pengobatan penyakit hati dalam bimbingan konseling Islam dapat dijelaskan sebagai berikut. Pertama: sesuai dengan pengertian bimbingan konseling Islam yang dikemukakan oleh Ainur Rahim Faqih, BKI adalah proses pemberian bantuan kepada individu agar mampu hidup selaras dengan ketentuan Allah sehingga mencapai kebahagiaan dunia dan akhirat. Dalam proses mencapai kebahagiaan inilah tanpa disertai dengan hati yang sehat, seseorang tidak akan berhasil. Oleh sebab itu, hati yang terbebas dari nafsu negatif akan selalu mendapat bimbingan dari Tuhan yang akhirnya mampu memaknai hidup. Kedua: sesuai dengan konsep dasar dari BKI yang menempatkan agama sebagai kebutuhan yang fitri, maka konsep pengobatan penyakit hati menurut Ibnu Taimiyah juga tidak menggunakan dasar konseptual selain agama itu sendiri yang bersendikan dari tekstualitas al-Qur'an dan Hadist. Ketiga, sesuai dengan landasan BKI yang menempatkan al-Qur'an dan Sunnah sebagai otoritas puncak yang berposisi sebagai dalil naqliah yang dipadukan dengan dalil aqliyah yang terdiri dari filsafat dan ilmu. Hal ini selaras dengan rancangan konseptual pengobatan penyakit hati menurut Ibnu Taimiyah yang memang menjadikan al-Qur'an dan Hadits sebagai kajian pokok.

Dari sinilah, konsep pengobatan penyakit hati menurut Ibnu Taimiyah sangat padu untuk diimplementasikan dalam BKI karena memiliki visi dan orientasi yang sama dalam rangka pengembangan kepribadian secara Qurani.

\section{KESIMPULAN}

Menurut Ibn Taimiyah, ada tiga hal yang dapat dijadikan sebagai obat penyakit hati, yaitu al-Qur'an, amal saleh, dan meninggalkan ma'siat. 


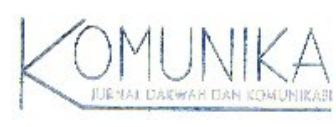

Pertama, menurut Ibn Taimiyah, al-Qur'an adalah penyembuh bagi penyakit hati yang berada di dalam dada dan bagi orang yang dalam hatinya ada penyakit keraguan dan syahwat. Di dalamnya terdapat keterangan-keterangan yang menghilangkan kebatilan dan syubhat yang dapat merusak ilmu, pemahaman dan kesadaran hingga segala sesuatu secara hakiki. Di dalamnya juga terdapat hikmah dan nasehat yang baik, seperti dorongan berbuat baik, ancaman dan kisah-kisah yang di dalamnya terdapat pelajaran yang berpengaruh pada sehatnya hati. Hati akan menjadi cinta kepada hal yang bermanfaat dan benci kepada hal yang membawa kepada kesengsaraan. Akhirnya, hati menjadi cinta kepada petunjuk dan benci kepada kesesatan, setelah pada mulanya condong kepada penyimpangan dan antipati terhadap petunjuk. Al-Qurân juga merupakan penyembuh dari penyakit yang mendorong kepada kehendak-kehendak buruk. Dengan al-Qur'an, hati dan kehendak menjadi sehat serta kembali kepada fitrahnya, sebagaimana kembalinya badan pada keadaan yang semula yaitu nilai-nilai keimanan dan al-Qur'an yang membawanya kepada keesucian dan menolongnya untuk melakukan perbuatan baik.

Kedua, amal saleh sebagai obat penyakit hati. Menurutnya, hati membutuhkan pemeliharaan supaya dapat berkembang dan bertambah baik menuju kesempurnaan dan kebaikan, sebagaimana tubuh memerlukan makanan yang bergizi. Oleh karena itu, wajib hukumnya untuk mencegah badan dari hal-hal yang dapat membawa pada kemudaratan. Badan tidak akan dapat berkembang dengan baik tanpa memberinya hal yang bermanfaat dan mencegahnya dari hal yang memudaratkannya. Demikian pula hati, ia tidak akan berkembang dengan baik atau mencapai kesempurnaan tanpa memberinya sesuatu yang bermanfaat dan menolak hal-hal yang membawa pada kemudaratan. Demikian pula halnya dengan tanaman, ia tidak akan tumbuh kecuali dengan hal ini. Oleh karena itu, tatkala sedekah dapat menghapus kesalahan, sebagaimana air dapat memadamkan api maka perbuatan baik dapat mensucikan hati dari dosa.

Ketiga, meninggalkan maksiat sebagai obat penyakit hati. Menurutnya, perbuatan keji dan munkar tak ubahnya seperti campuran kotoran dalam badan dan seperti benalu bagi tanaman. Oleh karena itu apabila badan telah bersih darinya maka sehatlah badan tersebut. Demikian pula hati, apabila ia telah bertobat dari dosa-dosa, seolah-olah ia telah menyucikan dari segala yang hal buruk. Oleh sebab itu, apabila hati telah bertobat dari segala dosa, maka akan kembalilah kekuatan hati dan siap untuk menjalankan amalan baik, di samping juga beristirahat dari segala hal yang sifatnya buruk.

Menurut Wahib Mu'thi, konsep pengobatan penyakit hati yang tiga tersebut dapat diperinci menjadi beberapa varian, yaitu benar dan ikhlas, taubat, zuhud, wara, sabar, syukur, tawakal, rela kepada Allah, takut, dan mengharap. Macammacam pengobatan hati tersebut merupakan sebagian dari apa yang dikemukakan oleh sufi sebagai al-maqomat dan alakhwal, yaitu tahapan-tahapan dan keadaan-keadaan ruhani dalam mendekatkan diri kepada Allah.

\section{ENDNOTE}

${ }^{1}$ Haedar Nasir, Agama dan Krisis Kemanusiaan Modem (Yogyakarta: Pustaka Pelajar, 1997), hal. 15.

${ }^{2}$ Victore Frank, Man's Search for Meaning, Revised and Update(Washington: Square Press, 1985), hal. 178.

${ }^{3}$ Ahmad Najib Burhani, Manusia Modem Mendamba Allah, Renungan Tasawuf Positf(Jakarta: Hikmah, 2002), hal. 175.

${ }^{4}$ Zakiah Darajat, Kesehatan Mental (Jakarta: Gunung Agung, 1983), hal. 23.

${ }^{5}$ Kartini Kartono, Hyegiene Mental dan Kesehatan Mental (Bandung: Mandar Maju, 1989), hal. 4.

${ }^{6}$ Hanna Djumhana Bastaman, Integrasi Psikologi dengan Islam (Yogyakarta: Yayasan Insan Kamil-Pustaka Pelajar Offset, 2001), hal. 147.

${ }^{7}$ Hemowo Dan M. Deden Ridwan, Aa Gym dan Fenomena Daanut Tauhid: Memperbaiki Diri Lewat Manajemen Qalbu (Bandung: Hikmah-Mizan, 2002), hal. 226-227.

${ }^{8}$ lbnu Taymiyah, Terapi Penyakit Hat (Jakarta: Gema Insani, 1998), hal. 78.

${ }_{9}^{9}$ Amir Said Az-Zaibari, Manajemen Kalbu (Yogyakarta: Mitra Pustaka, 2002), hal. 212-213.

${ }^{10}$ Pengurus Pusat Muhammadiyah, Dakwah Kultural Muhammadiyah (Yogyakarta: Suara Muhammadiyah, 2004), hal. 3.

${ }_{11}^{11}$ Asep Kusnawan, IImu Dakwah: Kajian dari Berbagai Aspek (Bandung: Pustaka Bani Quraish, 2004), hal. 9.

${ }_{12}^{12}$ Ahmad Mubarok, Jiwa dalam al-Quran: Solusi Krisis Kenuhanian Manusia Modem (Jakarta: Paramadina, 2000), hal. 246.

${ }_{13}$ Victorian, Donall, Persuation and Interaktive Dependency Approach (New York: Random House, 1982), hal. 246.

${ }^{14}$ Munzier Suparta dan Harjani Hefni, Metode Dakwah (Jakarta: Rachmad Semesta, 2003), hal. 4.

${ }^{15}$ Muhammad, Husain, Metodologi Dakwah Dalamal-Quran: Pegangan Bagi Para Aktifis, terj. Ahmad Qosim (Jakarta: Lentera, 1997 ), hal. 15. 
${ }^{16}$ Ainur Rachim Fakih, Bimbingan Konseling dalam Islam (Yogyakarta: Ull Press, 2001), hal. 4, lebih lanjut Menurut Ainur Rahim Faqih, Bimbingan dan Konseling Islam adalah proses pemberian bantuan terhadap individu agar mampu hidup selaras dengan ketentuan Allah sehingga dapat mencapai kebahagiaan di dunia dan di akhirat, sedangkan menurut Hallen, Bimbingan dan Konseling Islam adalah suatu usaha membantu individu dalam menanggulangi penyimpangan perkembangan Fitrah beragama yang dimilikinya sehingga ia kembali menyadari peranannya sebagai khalifah di bumi dan berfungsi untuk menyembah mengabdi kepada Allah SWT sehingga akhimya tercipta kembali hubungan yang baik dengan Allah, dengan manusia dan alam semesta (lihat Hallen, A, Bimbingan dan Konseling (Jakarta: Lentera, 1997), hal. 22. Adapun menurut Hamdani Bakran, Bimbingan dan Konseling Islam adalah suatu aktivitas memberikan bimbingan, pelajaran dan pedoman kepada individu yang meminta bimbingan (klien) dalam hal bagaimana sehingga seorang klien dapat mengembangkan potensi akal pikirannya, kepribadiannya, keimanan dan keyakinannya sehingga dapat menanggulangi problematika hidup dengan baik dan benar secara mandiri yang berpandangan pada Al-Qur'an dan As-Sunnah Rasulullah SAW (Lihat Hamdani Bakran Adz-Dzaky, Bimbingan Konseling Islam (Yogyakarta: Pustaka Pelajar, 2001), hal 137). Dari ketiga definisi konseling di atas menunut Mapiare, memuat unsur-unsur konseling yang meliputi: suatu proses, adanya seseorang yang dipersiapkan secara profesional, membantu orang lain, untuk pemahaman diri, pembuatan keputusan dan pemecahan masalah, pertemuan dari hati ke hati dan hasilnya sangat bergantung pada kualitas hubungan, maka dapat diperoleh kesimpulan bahwa tidak satupun dari ketiganya yang mampu memenuhi keenam unsur tersebut. Rata-rata kegiatannya hanya mampu memenuhi unsur pertama, ketiga dan keempat. Sementara itu, unsur-unsur kedua, kelima dan keenam terkover lihat Andi Mappiare, Bimbingan Penyuluhan Islam (Yogyakarta: Andi Offset, 1992), hal. 16. Oleh sebab itulah, definisi Bimbingan dan Konseling Islam yang penulis rumuskan di bawah ini diharapkan mampu memenuhi keenam unsur tersebut. Menurut penulis, Bimbingan dan Konseling Islam adalah suatu proses hubungan pribadi yang terprogram, antara seorang konselor dengan satu atau lebih klien di mana konselor dengan bekal pengetahuan profesional dalam bidang keterampilan dan pengetahuan psikologis yang dikombinasikan dengan pengetahuan keislamannya membantu klien dalam upaya membantu kesehatan mental sehingga dari hubungan terebut klien dapat menanggulangi problematika hidup dengan baik dan benar secara mandir yang berpandangan pada al-Qur'an dan as-Sunnah".

${ }_{17}$ Thohari Musnamar, Dasar-dasar Konseptual Bimbingan dan Konseling Islam (Yogyakarta: UII Press, 1992), hal. 34.

${ }^{18}$ Ibnu Taimiyah, Mengenali Gerak-Gerik Kalbu (Bandung: Pustaka Hidayah, 2001), hal. 149.

${ }_{19}$ Sebagai perbandingan, Penyakit hati menunut HAMKA, terdiri dari: marah, ujub, membanggakan diri sendir, mengolok-olok orang lain, dendam, dan mangkir dari janji. Menurut Amin Syukur, penyakit hati terdiri dari: marah, egois, dengki, sombong, kikir, boros, mudah berkeinginan, buruk sangka dan berbohong, sedangkan menunut Mujtaba Musawi, penyakit hati terdir dari: pemberang, pesimis, dusta, munafik, ghibah, mencari-cari kesalahan orang lain, dengki, sombong, zalim, marah, melanggar janji, khianat, kikir, dan serakah.

${ }^{20}$ Ibnu Taimiyah, Terapi Penyakit Hati (Jakarta: Gema Insani, 1998), hal. 13.

${ }^{21}$ Ibnu Taimiyah, Mengenali Gerak-genik Kalbu, hal. 200.

2 Sebagai pembanding menunut Yunasril Ali, mengobati penyakit hati salah satunya dapat ditempuh dengan mensucikan hati yang merupakan perpaduan dari konsep menjemihkan kalbu dan mendekatkan dir kepada Allah Swt, sehingga lebih terfokus pada kiat-kiat sufiyah. Memang patut disayangkan apabila hati yang potensial tersebut harus terhalang dan hilang kemampuannya, apalagi jika sampai menjadi buta sebagaimana dinayatakan oleh surat al Haj (22:46). Buta hat jauh lebih berbahaya ketimbang buta mata, karena orang yang buta hatinya dapat merusak siapa saja dan apa saja yang ada, termasuk dirinya sendiri. Di sini pentingnya kita memperhatikan, merawat dan mendidik hati kita masing-masing. Betapa sesalnya orang yang dalam hidupnya tak pemah menyadari betapa pentingnya pendidikan bagi hatinya. Betapa beruntungnya orang yang sepenuhnya sadar akan pentingnya memperhatikan kebeningan hatinya. Lihat Yunasril Ali, Ruh dan Jenjang-jenjang Ruhani (Jakarta: Serambi Ilmu Semesta, 2003$)$, hal. 47.

${ }^{23}$ Ibnu Taimiyah, Mengenali Gerak-genik Kalbu, hal. 187.

${ }^{24}$ Ibid., hal. 154.

${ }^{25}$ Wahib Mu'thi, Terapi hati dengan Pendekatan Suffyah (Yogyakarta: Lentera 1994), hal. 71.

${ }^{20}$ Ibid., hal. 72.

${ }^{27}$ Ibnu Taimiyah, Risalah Tasawuf(Jakarta: Hikmah, 2002), hal. 136.

${ }^{23}$ Ibnu Taymiyah, Terapi Penyakit Hati, hal. 21.

${ }^{2}$ Ibnu Taimiyah, Mengenali Gerak-Gerik Kalbu, hal. 234.

${ }^{30}$ Ibnu Taimiyah, Risalah Tasawuf, hal. 11.

${ }^{31}$ Ibnu Taimiyah, Terapi Penyakit Hati, hal. 212.

${ }^{32}$ Ibnu Taimiyah, Risalah Tasawur, hal. 173.

${ }_{33}$ Yunasril Ali, Jatuh Hati Pada llahi (Jakarta: Serambi llmu Semesta, 2003), hal. 7.

${ }^{34}$ Hanna Djumhanna Bastaman, Integrasi Psikologi dengan Islam: Menuju Psikologi Islami (Yogyakarta: Pustaka Pelajar, 1997), hal. 28.

${ }^{35}$ Wahib Mu'thi, Terapi Hati dengan Pendekatan Sufistik, hal. 70.

${ }^{3}$ Aep, Kusnawan, IImu Dakwah: Kajian dari Berbagai Aspek (Bandung: Pustaka bani Quraish, 2004), hal. 180-181.

${ }^{37}$ Muhammad Damami, Tasawuf Positif: Dalam Pemikiran HAMKA (Yogyakarta: Fajar Pustaka, 2000), hal. 218.

${ }^{3}$ Hanna Djumhanna Bastama, Integrasi Psikologi dengan Islam, hal. 210-212. 


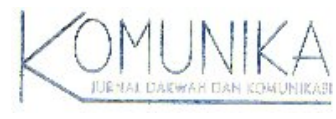

${ }^{3}$ Asep Kusnawan, IImu Dakwah, hal. viii.

\section{DAFTAR PUSTAKA}

Adz-Dzaky, Hamdani Bakran. 2001. Bimbingan Konseling Islam. Yogyakarta: Pustaka Pelajar.

Ali, Yunasi. 2003. Jatuh Hati Pada llahi. Jakarta: Serambi llmu Semesta.

. 2003. Ruh dan Jenjangjenjang Ruhani. Jakarta: Serambi llmu Semesta.

Az-Zaibari, Amir Said. 2002. Manajemen Kalbu. Yogyakarta: Mitra Pustaka.

Bastaman, Hanna Djumhana. 2001. Integrasi Psikologi dengan Islam. Yogyakarta: Yayasan Insan Kamil-Pustaka Pelajar Offset.

Burhani, Ahmad Najib. 2002. Manusia Modem Mendamba Allah, Renungan Tasawuf Positif. Jakarta: Hikmah.

Damami, Muhammad. 2000. Tasawuf Positif: dalam Pemikiran Hamka. Yogyakarta: Fajar Pustaka.

Darajat, Zakiah. 1983. Kesehatan Mental. Jakarta: Gunung Agung.

Donall, Victorian. 1982. Persuation and Interaktive Dependency Approach. New York: Random House.

Fakih, Ainur Rachim. 2001. Bimbingan Konseling dalam Islam. Yogyakarta: UII Press.

Frankl, Victore. 1985. Man's Search for Meaning, Revised and Update. Washington: Square Press.

Hallen, A. 1997. Bimbingan dan Konseling. Jakarta: Lentera.

Hemowo dan M. Deden Ridwan. 2003. Aa Gym dan Fenomena Daant Tauhid: Memperbaiki Dir Lewat Manajemen Qalbu. Bandung:

Hikmah-Mizan.

Kartono, Kartini. 1989. Hyegiene Mental dan Kesehatan Mental. Bandung: Mandar Maju.

Kusnawan, Asep. 2004. IImu Dakwah: Kajian dari Berbagai Aspek. Bandung: Pustaka Bani Quraish.

Mappiare, Andi. 1992. Bimbingan Penyuluhan Islam. Yogyakarta: Anndi Offset.

Mu'thi, Wahib. 1994. Terapi hati dengan Pendekatan Sufryah. Yogyakarta: Lentera.

Mubarok, Ahmad. 2000. Jiwa dalam al-Quran: Solusi Krisis Keruhanian Manusia Modem. Jakarta: Paramadina.

Muhammad, Husain. 1997. Metodologi Dakwah dalam al-Quran: Pegangan Bagi Para Aktifis. Terj. Ahmad Qosim. Jakarta: Lentera.

Musnamar, Thohari. 1992. Dasar-dasar Konseptual Bimbingan dan Konseling Islam. Yogyakarta: UII Press.

Nasir, Haedar. 1997. Agama dan Krisis Kemanusiaan Modem. Yogyakarta: Pustaka Pelajar.

Pengurus Pusat Muhammadiyah. 2004. Dakwah Kultural Muhammadiyah. Yogyakarta: Suara Muhammadiyah.

Suparta, Munzier dan Hajjani Hefni. 2003. Metode Dakwah. Jakarta: Rachmad Semesta.

Taimiyah, Ibnu. 1998. Terapi Penyakit Hati. Jakarta: Gema Insani.

. 2001. Mengenali Gerak-genik Kalbu. Bandung: Pustaka Hidayah.

. 2002. Risalah Tasawuf. Jakarta: Hikmah. 